Check for updates

London, UK

Cite this as: $B M J 2021 ; 374:$ n1946 http://dx.doi.org/10.1136/bmj.n1946 Published: 16 August 2021

\title{
Supporting victims of sexual assault: the forensic medicine doctor
}

\section{Specialty doctor Bernadette Butler cares for patients who have been raped or sexually assaulted. She talks to Helen Jones about her work and the importance of forensic medicine}

\section{Helen Jones}

"It can be difficult work but knowing that we offer patients somewhere to get help and advice helps me to cope," says Bernadette Butler.

She is clinical education and training lead for the Havens, a group of three specialist centres run by King's College Hospital NHS Foundation Trust for anyone who has been raped or sexually assaulted.

Forensic medicine is, Butler says, incredibly important given how common sexual assault is. "Sexual violence is a major public health problem, as are all types of interpersonal violence. In England and Wales more than 150 ooo sexual assaults and rapes are reported to the police each year. However, evidence from surveys of those over the age of 16 years shows fewer than $20 \%$ of offences are reported to police," she says. "So it is essential to have appropriately trained clinicians and specialist staff in sexual assault referral centres and other services to provide the forensic and therapeutic care a person may need, without having to report the incident to the police if they don't wish to.”

Because of the nature of the work they do, the team at the Haven service are very supportive of one another. "Often my crisis worker colleague is the first person to whom someone will disclose an incident," Butler says.

Butler and her fellow forensic physicians believe that forensic medicine should be given specialty status. "This will improve standards in patient care, better serve justice-in all its aspects and settings-and, through research, education, and training, provide excellent and safe care for those who experience sexual violence," she says. Butler and her colleagues are also trying to ensure forensic medicine is on the syllabus of all medical schools.

But she didn't plan a career in forensic medicine. During her training Butler did jobs in obstetrics and gynaecology and pathology, and preferred the former because she enjoyed talking to people.

After starting a family, she decided to step off the career ladder to have more time to care for her children, and she worked part time in gynaecology.

"As the children grew I had more time but I was intimidated by the membership examination of the Royal College of Obstetricians and Gynaecologists, which had a low pass rate. I also wasn't sure if I was 'consultant material' so I carried on part time gynaecology work.”

Eventually Butler took the exam and passed on her second attempt. Her failure the first time was "an important and useful lesson," she says. "We can’t always be successful in everything we do.”
In 2000 Butler responded to an advertisement in The $B M J$ for a role in a pilot sexual assault service in south London, which became the Camberwell Haven.

"I suppose it was serendipity that I found something that suited me. I have an interest in the law-I've been a lay magistrate for over 20 years-and this was an opportunity to combine that with my existing skills and knowledge, as well as gaining new ones. Twenty one years later I'm still doing it," she says.

Butler's role is a varied one. "I organise induction and training for clinicians-many of our staff have other jobs in gynaecology or sexual health or are GPs," she says. "I also chair some clinical meetings and I'm part of our senior doctor rota, advising colleagues when required. I do my clinical work at night and weekends, which involves taking referrals from the police, arranging a forensic medical examination, if appropriate, and providing follow-up care and advice.”

Her patient group is exceptionally vulnerable. "We see many children and young people and people with intellectual disability or problems with their mental health or substance use, or who are homeless.

Sometimes this may be the only holistic examination and assessment they will have."

Butler appreciates the time she is able to spend with these patients. "A visit to the Haven often lasts for three or four hours. As well as the forensic aspects, we discuss consent, confidentiality, sexual health, and therapeutic care, but there is also an opportunity to identify other medical and psychosocial needs-I recently saw someone who had significant untreated hypertension and a child with a cardiac murmur, and both needed referral."

It's not an easy job and Butler values the support of her colleagues as well as her family. "I also benefit from being at home, in the garden, cooking, my faith and beliefs, and walking Byron, the dog," she says. "Work like this also requires more formal supervision, talking through how this work affects you, but it is incredibly rewarding."

\section{Nominated by Emmeline Brew-Graves}

I've known Bernadette-known as Dr B-since 2007. I was working as a GP and wanted to return to forensic medicine. I started working at the Havens a day a week and, with her support and encouragement, l've transitioned to being a sexual offences examiner and have retired from general practice.

I can say without hesitation that Bernadette Butler changed my life. She encourages all of us who know her professionally to be reflective in our practice and development. She respects every single member of our large multidisciplinary team equally. She is extremely 
hardworking-she's that rare ideas person who's also an implementer and finisher. She never expects anyone to complete a task that she isn't happy to complete herself. She leads by doing and is thorough and conscientious. She forms a true partnership with every patient she sees and embodies patient centred care.

This role is incredibly wide and yet she officially does it in two days a week, but that's only because she is superhuman. She is the only person I know who I can confidently say has a moral compass that points "true north."

Emmeline Brew-Graves is a sexual offences examiner 